\title{
Corneal Haze and Pars Planitis
}

\author{
Amro Ali*, Thaddeus L Wandel and Sansar C Sharma \\ Department of Ophthalmology, New York Medical College, USA \\ *Corresponding author: Amro Ali, MD. MO, 40 Sunshine Cottage Road, Valhalla, NY 10595, New York, USA
}

Submission: 眥 October 26, 2017; Published: 眥 May 03, 2018

\begin{abstract}
Importance: Pars planitis is a disease that occurs in healthy young adults or children that commonly leads to significant visual loss. Although pars planitis is a diagnosis of exclusion, there is a lack of agreement in the literature pertaining to the clinical findings observed in patients with pars planitis. Corneal haze was not described before in this context and its presence may help with early diagnosis of pars planitis.
\end{abstract}

Objective: The primary objective of this study was to assess the presence of corneal haze in patients with pars planitis, especially in the absence of Keratic precipitate (KP).

Design: Case series study included six patients with an established diagnosis of pars planitis that were seen by the Uveitis Service between 2009 and 2011. Setting: New York Medical College

Participants: Six patients with pars planitis that were examined between 2009 and 2011.

Main Outcomes and Measures: Main outcome measures include findings observed on slit lamp examination, such as anterior chamber inflammation, KP, corneal haze, vitritis, vasculitis, and cystoid macular edema (CME).

Results: All six patients demonstrated anterior chamber inflammation, vitritis, and corneal haze without KP except for one patient. Retinal vasculitis was appreciated in two patients on clinical fundus examination and confirmed by fluorescein angiography. Cystoid Macular edema (CME) was appreciated in three patients, and confirmed using Optical coherence tomography (OCT).

Conclusions and Relevance: In previous case reports, corneal haze was found in the inferior cornea zone with the presence of KP along the junction between affected and unaffected cornea. As most of our patients (five out of six patients) demonstrate corneal haze in the absence of KP, we concluded that the presence of KPs is not a key factor in the pathophysiology of inferior corneal haze development, and the condition remains permanent even after good control of inflammation. Because of this, different theories may be used to explain the presence of corneal haze in pars planitis.

Abbreviations: KP: Keratic precipitate; CME: Cystoid Macular Edema; OCT: Optical Coherence Tomography; IU: Intermediate Uveitis; SUN: Standardization of Uveitis Nomenclature; MTX: Methotrexate

Key Points

a. The primary objective was to determine the slit lamp examination findings associated with pars planitis to aid in its diagnosis.

b. In this case series, all six patients with an established diagnosis of pars planitis demonstrated anterior chamber inflammation, vitritis, and corneal haze. Corneal involvement was without presence of Keratic precipitate, except for one patient.

c. Corneal haze, with or without Keratic precipitate, is a new finding that can be used to help other ophthalmologists in the diagnosis of pars planitis.

\section{Introduction}

Intermediate uveitis (IU) is inflammation of the anterior vitreous, ciliary body, and peripheral retina. In the Standardization of Uveitis Nomenclature (SUN) working group's international workshop for reporting clinical data a consensus was reached that IU should be used to refer to the subset of uveitis with vitreous as the major site of inflammation and when there's an associated infection (e.g., Lyme disease) or systemic disease (e.g., sarcoidosis) [1].

Pars planitis is a benign condition that occurs in healthy young adults or children. It's typically associated with mild vision loss, except when complicated with cystoid macular edema (CME) and associated with profound vision loss [2,3]. The first observable symptom of pars planitis is commonly floaters or vitreous cells in active vitritis. On examination, the eye looks quiet externally, but mild anterior chamber inflammation, vitreous opacities, snowballs and snow exudates can be observed on slit lamp examination. CME 
or cataract, especially posterior subcapsular cataract, may also be present. Inflammatory mediators increase vasopermeability of retinal capillaries causing posterior segment inflammation and CME. Topical steroid is rarely indicated. Oral prednisone is more commonly used in bilateral pars planitis. In severe cases, periocular steroid injection is indicated, especially with associated CME. For this study, retrospective chart review was performed for six patients with established diagnoses of pars planitis. We present the cases with accompanying ocular examination findings, which are summarized in Tables $1 \& 2$.

Table 1: Patient Sociodemographic Information and Overview of Slit-Lamp Examination Findings.

\begin{tabular}{|c|c|c|c|c|c|c|c|c|c|c|}
\hline Case \# & Race & Age & Sex & Laterality & AC inflammation & KP & $\begin{array}{c}\text { Corneal } \\
\text { haze }\end{array}$ & Vitritis & Vasculitis & CME \\
\hline 1 & White & 18 & F & Bilateral & Present & Absent & Present & Present & Present & Present \\
\hline 2 & Hispanic & 11 & M & Unilateral & Present & Present & Present & Present & Absent & Absent \\
\hline 3 & Hispanic & 5 & F & Bilateral & Present & Absent & Present & Present & Present & Absent \\
\hline 4 & White & 31 & M & Bilateral & Present & Absent & Present & Present & Absent & Present \\
\hline 5 & White & 14 & M & Bilateral & Present & Absent & Present & Present & Absent & Present \\
\hline 6 & Hispanic & 6 & F & Bilateral & Present & Absent & Present & Present & Absent & Absent \\
\hline
\end{tabular}

AC: Anterior Chamber; KP: Keratic Precipitates; CME: Cystoid Macular Edema

Table 2: Details from Ocular Examination

\begin{tabular}{|c|c|c|c|c|c|c|c|}
\hline Case \# & BCVA & $\begin{array}{l}\text { Pressure } \\
(\mathrm{mmHg})\end{array}$ & $\mathrm{AC}^{*}$ & Vitritis* & Other SLE findings & CDR & Other DFE findings \\
\hline \multicolumn{8}{|c|}{1 (Initial Examination) } \\
\hline OD: & $20 / 25$ & 14 & $0.5+$ & 0 & $\begin{array}{l}\text {-Inf. corneal haze } \\
\text {-Lens clear }\end{array}$ & 0.3 & $\begin{array}{c}\text {-CME } \\
\text {-Sheathing along major } \\
\text { retinal vessels } \\
\text {-No snowballs } \\
\text {-No snowbanks }\end{array}$ \\
\hline OS: & $20 / 25$ & 15 & $0.5+$ & 0 & $\begin{array}{l}\text {-Inf. corneal haze } \\
\quad \text {-Lens clear }\end{array}$ & 0.3 & $\begin{array}{c}\text {-CME } \\
\text {-Sheathing along major } \\
\text { retinal vessels } \\
\text {-No snowballs } \\
\text {-No snowbanks }\end{array}$ \\
\hline \multicolumn{8}{|c|}{2 (Initial Examination) } \\
\hline OD: & $20 / 20$ & 14 & 0 & $\begin{array}{l}-2+\text { cells - } \\
\text { Trace haze }\end{array}$ & $\begin{array}{l}\text {-Cornea clear } \\
\text {-Lens clear }\end{array}$ & 0.2 & $\begin{array}{c}\text {-Flat macula } \\
\text {-Normal vessels } \\
\text {-Confluent snowballs in } \\
\text { lower periphery }<\mathrm{OS} \\
\text {-Pars plana snow banks }<\mathrm{OS}\end{array}$ \\
\hline OS: & $20 / 200$ & 12 & 0 & $\begin{array}{l}-3+\text { cells - } \\
\text { Many veils } \\
\text { and } \\
\text { clumps }\end{array}$ & $\begin{array}{c}\text {-Inf. perilimbal band of } \\
\text { descemet opacification } \\
\text {-Diffuse endothelial } \\
\text { haze } \\
\text {-Fine pigmented KPs } \\
\text {-Lens clear }\end{array}$ & 0.2 & $\begin{array}{c}\text {-Macula difficult to assess } \\
\text { due to vitritis } \\
\text {-Normal vessels } \\
\text {-Confluent snowballs in } \\
\text { lower periphery> OD } \\
\text {-Pars plana snow banks> OD }\end{array}$ \\
\hline \multicolumn{8}{|c|}{3 (Initial Examination) } \\
\hline OD: & $20 / 80$ & 15 & $2+$ & $\begin{array}{l}-1+\text { cells } \\
- \text { No haze }\end{array}$ & $\begin{array}{l}\text {-Inf. corneal haze } \\
\text {-Lens clear }\end{array}$ & 0.1 & $\begin{array}{c}\text {-Flat macula } \\
\text {-Sheathing along peripheral } \\
\text { retinal vessels }\end{array}$ \\
\hline
\end{tabular}




\begin{tabular}{|c|c|c|c|c|c|c|c|}
\hline & & & & & & & $\begin{array}{c}\text {-Snowballs present } \\
\text {-No snow bank } \\
\text {-Peripheral atrophic white } \\
\text { lesions }\end{array}$ \\
\hline OS: & $20 / 80$ & 13 & $2+$ & $\begin{array}{l}-1+\text { cells } \\
- \text { No haze }\end{array}$ & $\begin{array}{l}\text {-Inf. corneal haze } \\
\text {-Lens clear }\end{array}$ & 0.1 & $\begin{array}{c}\text {-Flat macula } \\
\text {-Sheathing along peripheral } \\
\text { retinal vessels } \\
\text {-Snowballs present } \\
\text {-No snow bank } \\
\text {-Peripheral atrophic white } \\
\text { lesions }\end{array}$ \\
\hline \multicolumn{8}{|c|}{4 (Initial Examination) } \\
\hline OD: & $20 / 30$ & 13 & $1+$ & $\begin{array}{l}-1+\text { cell } \\
-1+\text { haze }\end{array}$ & $\begin{array}{l}\text {-Cornea with subtle } \\
\text { deep stromal haze } \\
\text {-Lens clear }\end{array}$ & 0.3 & $\begin{array}{c}\text {-Flat macula } \\
\text {-Normal vessels } \\
\text {-Snowballs present } \\
\text {-Snow bank } \\
\end{array}$ \\
\hline OS: & $20 / 15$ & 14 & $0.5+$ & $\begin{array}{l}-0.5+\text { cell } \\
- \text { No haze }\end{array}$ & $\begin{array}{l}\text {-Cornea clear } \\
\text {-Lens clear }\end{array}$ & 0.3 & $\begin{array}{c}\text {-Flat macula } \\
\text {-Normal vessels } \\
\text {-Snowballs present } \\
\text {-Snow bank present }\end{array}$ \\
\hline \multicolumn{8}{|c|}{5 (Most Recent Examination) } \\
\hline OD: & $20 / 25$ & 13 & $1+$ & 0 & $\begin{array}{l}\text {-Cornea clear } \\
-1+\text { PSC }\end{array}$ & 0.3 & $\begin{array}{c}\text {-Flat macula } \\
\text {-Normal vessels } \\
\text {-No snowballs } \\
\text {-No snow bank } \\
\text {-Cryotherapy scars in far } \\
\text { periphery }\end{array}$ \\
\hline OS: & $20 / 40$ & 15 & $1+$ & 0 & $\begin{array}{c}\text {-Inferior corneal haze } \\
\text {-Aphakic }\end{array}$ & 0.3 & $\begin{array}{c}\text {-Flat macula } \\
\text {-Normal vessels } \\
\text {-Confluent masses of } \\
\text { snowballs in lower periphery } \\
\text {-No snow bank } \\
\text {-Cryotherapy scars in far } \\
\text { periphery }\end{array}$ \\
\hline \multicolumn{8}{|c|}{6 (Initial Examination) } \\
\hline OD: & $20 / 50$ & 19 & $1+$ & $\begin{array}{l}-1+\text { cell } \\
-1+\text { haze }\end{array}$ & $\begin{array}{l}\text {-Inf. corneal haze } \\
\text {-Lens clearc }\end{array}$ & 0.4 & $\begin{array}{c}\text {-Flat macula } \\
\text {-Normal vessels } \\
\text {-Snowballs present } \\
\text {-No snow bank }\end{array}$ \\
\hline OS: & $20 / 40$ & 17 & $1+$ & $\begin{array}{l}-1+\text { cell } \\
-1+\text { haze }\end{array}$ & $\begin{array}{l}\text {-Inf. corneal haze } \\
\text {-Lens clear }\end{array}$ & 0.4 & $\begin{array}{c}\text {-Flat macula } \\
\text {-Normal vessels } \\
\text {-Snowballs present } \\
\text {-No snow bank }\end{array}$ \\
\hline
\end{tabular}


AC inflammation and vitreous inflammation graded according to SUN criteria*.

BCVA: Best-Corrected Visual Acuity; AC: Anterior Chamber; SLE: Slit-Lamp Examination; CDR: Cup-to-Disc Ratio; DFE: Dilated Fundus Examination; CME: Cystoid Macular Edema; PSC: Posterior Subcapsular Cataract

\section{Case 1}

An 18-year-old white female with a history of recurrent bilateral uveitis was initially seen in July 2009. She complained of blurred vision and floaters in both eyes. Her last flare-up was in July 2007 when she was started on Remicade $3 \mathrm{mg} / \mathrm{kg}$ every 8 weeks and oral Methotrexate (MTX) 7.5mg/week. At this visit, bilateral pars planitis flare-up was diagnosed, and she was treated with a short course of oral prednisone with favorable response. A refractory CME was treated with an additional short course of oral prednisone. In an attempt to control symptoms and wean her off the oral prednisone, her maintenance medication doses were increased to Remicade $5 \mathrm{mg} /$ day every 8 weeks and MTX $12.5 \mathrm{mg} /$ week. Oral MTX was stopped in January 2010 due to gastrointestinal side effects. She was then started on Cyclosporine, which was discontinued due to gingival hyperplasia. Remicade was stopped in March 2010, and there has been no additional flare-up.

\section{Case 2}

An 11-year-old Hispanic boy was first seen in our uveitis clinic in June 2005 after failing his school vision test. He described oneyear of blurred vision and floaters in the left eye. He was diagnosed with par planitis OS. After a short course of oral prednisone, BCVA of the left eye improved from $20 / 200$ to $20 / 50$, but the patient could not tolerate the side effects, such as weight gain. The patient then started $15 \mathrm{mg}$ subcutaneous MTX, which was increased to $25 \mathrm{mg}$ in July 2008. The patient's inflammation is controlled with this regimen, and there has been no additional flare-up since June 2005.

\section{Case 3}

A 5-year-old Hispanic female was first seen in February 2009. Her mother had first noticed a spot in the left eye and then another spot in the right. The pediatrician confirmed the presence of ocular lesions, and referred her for ophthalmologic assessment. She was diagnosed with pars planitis OU. Treatment was a short course of topical prednisolone that improved vision to 20/20. At her last visit in December 2009, she had no inflammation almost 6 months after discontinuing topical prednisolone.

\section{Case 4}

A 31-year-old white female with a history of pars planitis OU presented 8-weeks postpartum in August 2009. She complained of worsening blurry vision and floaters in both eyes, worse in the right eye than the left. She denied pain, redness, flashes or photophobia. Her past flare-ups were treated with periocular kenalog injection of the left eye in February 2006, and the right eye in September 2006, which yielded favorable response in her vision. At this visit, she was treated with periocular kenalog injection OD, but BCVA continually decreased. Visual loss was attributed to vitritis, CME, and cataract. The patient was started on oral MTX, which was later discontinued due to side effects of skin rash, nausea and hair loss. Cellcept 1000 mg twice/day was started instead, and has since controlled inflammation.

\section{Case 5}

A 14-year-old white male presented in March 2003 for a second opinion regarding his asymptomatic recurrent bilateral uveitis. Pars planitis OU was confirmed, and treated with a short course of oral prednisone and subcutaneous MTX that was soon after switched to oral MTX. Oral MTX was discontinued in May 2005, as the disease remained quiescent. In May 2006, he had cataract extraction-aphakic OS, vitrectomy OS and cryotherapy OU. After surgery, the patient was asymptomatic but OCT showed marked CME OS. In March 2007, the patient was restarted on 15mg oral MTX and a short course of oral prednisone. In May 2008, the patient developed more inflammation and CME of the left eye. MTX dose was increased to $20 \mathrm{mg}$, and was switched from oral to subcutaneous form to increase medicine bioavailability. He was also started on a short course of oral prednisone. He was put back on oral MTX between June 2008 and June 2009. During his most recent exam, he was off MTX for two years without additional flare-up.

\section{Case 6}

A 6-year-old Hispanic female was seen in May 2008 after failing her school vision test. She reported no symptoms, and is healthy with no significant medical or surgical history. She was diagnosed with pars planitis OU. She was treated with a short course of oral prednisone and $15 \mathrm{mg}$ oral MTX, with favorable response. Later, MTX failed to control symptoms without additional oral prednisone. She was switched to oral Cellcept 750mg twice/ day with a short course of oral prednisone, but her inflammation continued to worsen. Medication options such as TNF-inhibitors were discussed with her family, but her family had concerns about side effects. She was switched to the subcutaneous form of MTX for higher bioavailability. The patient was last seen in May 2010, when examination showed evidence of active inflammation OU but improvement in BCVA to 20/25 OD and 20/30 OS. The rest of her examination was unchanged.

\section{Discussion}

Corneal haze was found in all six patients with an established diagnosis of pars planitis. In our case series, KPs were only found in one patient. In previous case reports, corneal haze is found in the inferior corneal zone accompanied by KPs along the junction of affected and unaffected cornea [4,5]. In fact, throughout pars planitis literature, KPs, stromal haze and exudates over trabecular meshwork are reported, but there are no cases without the presence of KPs [6,7]. Our study elucidates that KP presence is not obligatory for formation of inferior corneal haze, and the condition remains permanent even after good control of inflammation. The pathogenesis of corneal haze in such cases may be explained in a similar fashion to autoimmune endotheliopathy, another rare condition, since pars planitis mainly occurs in the vitreous. Vitreous 
inflammation leads to exudate and cytokine formation, which mainly falls to the inferior eye, eliciting an endotheliopathy-like reaction. Another theory for corneal haze pathogenesis involves vitreous inflammation causing delayed hypersensitivity.

\section{References}

1. Jabs DA, Nussenblatt RB, Rosenbaum JT (2005) Standardization of Uveitis Nomenclature (SUN) Working Group. Standardization of uveitis nomenclature for reporting clinical data. Results of the First International Workshop. Am J Ophthalmology 140(3): 509-516.

2. Dev S, Mieler WF, Pulido JS, Mittra RA (1999) Visual outcomes after pars plana vitrectomy for epiretinal membranes associated with pars planitis. Ophthalmology 106(6): 1086-1090.
3. Malinowski SM, Pulido JS, Folk JC (1993) Long-term visual outcome and complications associated with pars planitis. Ophthalmology 100(6): 818-824.

4. Paul RH (1988) Presumed autoimmune corneal endotheliopathy. Am J Ophthalmology 105(5): 519-522.

5. Sugar A, Smith T (1982) Presumed autoimmune corneal endotheliopathy. Am J Ophthalmol 94(5): 689-691.

6. Khodadoust AA, Attarzadeh A (1982) Presumed autoimmune corneal endotheliopathy. Am J Ophthalmology 93(6): 718-722.

7. Khodadoust AA, Kamama Y, Stoessel KM, Puklin JE (1986) Pars planitis and autoimmune endotheliopathy. Am J Ophthalmology 102(5): 633639.
Creative Commons Attribution 4.0 International License

For possible submissions Click Here

\section{MSOR Nersals 8} Ophistimalos
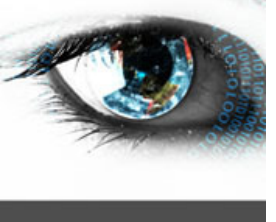

\section{Medical \& Surgical Ophthalmology Research}

\section{Benefits of Publishing with us}

- High-level peer review and editorial services

- Freely accessible online immediately upon publication

- Authors retain the copyright to their work

- Licensing it under a Creative Commons license

- Visibility through different online platforms 